\title{
POTENSI DAN PROSPEK SERTA PERMASALAHAN PENGEMBANGAN BUDIDAYA RUMPUT LAUT DI PROVINSI SULAWESI SELATAN
}

\author{
Abdul Malik Tangko* \\ *) Balai Riset Perikanan Budidaya Air Payau, Maros
}

\begin{abstract}
ABSTRAK
Provinsi Sulawesi Selatan cukup strategis, menyebabkan pembangunan perikanannya berkembang pesat termasuk di sektor budidaya rumput laut. Menonjolnya budidaya rumput laut di daerah ini disebabkan selain tempatnya yang strategis juga didukung oleh fasilitas budidaya yang cukup memadai seperti tersedianya lahan untuk budidaya Eucheuma sp. sekitar 193.700 ha dan untuk budidaya Gracilaria sp. di tambak tersedia lahan sekitar 50.201 ha. Di Sulawesi Selatan budidaya Gracilaria sp. di tambak dan Euchema sp. di laut telah berkembang yang cukup pesat. Di Sulawesi Selatan kedua jenis rumput laut ini telah dinobatkan sebagai ko mo ditas unggulan. Produksi rumput laut di Sulawesi Selatan pada tahun 2006 yaitu jenis Gracilaria sp. sebesar $15.144,8$ ton dengan nilai sebesar Rp 213.946,6,dan jenis Eucheuma sp. sebesar 403.201 ton dengan nilai sebesar Rp 604.801.500.000,--. Sistem budidaya Gracilaria sp. di tambak dilakukan dengan pola budidaya polikultur dengan bandeng dan udang windu, sedangkan sistem budidaya Eucheuma sp. di laut dilakukan dengan sistem rakit apung. Lama pemeliharaan Gracilaria sp. di tambak 45--60 hari/siklus, sedangkan Eucheuma sp. di laut sekitar 45 hari/siklus, sehingga panen dapat dilakukan 6 kali per tahun. Produksi Gracilaria sp. basah di tambak sekitar 7--12 ton/ha/siklus atau setara sekitar 700--1.200 kg Gracilaria sp. kering. Sedangkan produksi Eucheuma sp. basah hasil budidaya di laut sekitar 8--10 ton/unit rakit apung/ siklus, atau setara dengan 800--1.000 kg Eucheuma sp. kering.
\end{abstract}

KATAKUNCl: potensi, prospek, budidaya, Gracilaria sp., Eucheuma sp.

\section{PENDAHULUAN}

Provinsi Sulawesi Selatan posisinya cukup strategis karena selain sebagai pintu gerbang di kawasan timur Indonesia juga fasilitas transportasi yang menghubungkan antara kota Makassar sebagai ibu kota provinsi dengan berbagai daerah kabupaten yang tersebar di Sulawesi Selatan cukup lancar. Memadainya fasilitas perhubungan tersebut tentunya sangat mendukung kegiatan usaha budidaya perikanan termasuk kegiatan budidaya rumput laut, baik untuk kepentingan fasilitas budidaya maupun pemasaran hasil produknya. Fenomena alam dan lingkungan tersebut sangat mendukung pengembangan pembangunan perekonomian dari berbagai sektor termasuk sektor perikanan (Nontji, 2005).

Dari sektor perikanan, jenis komoditas yang sangat potensial untuk dikembangkan adalah budidaya rumput laut baik di tambak maupun di laut. Prospek pengembangan budidaya rumput laut tersebut selain didukung oleh letaknya yang cukup strategis juga didukung oleh sumberdaya lahan yang masih cukup luas yaitu lahan tambak untuk budidaya Gracilaria sp. sekitar 50.201 ha dan lahan budidaya rumput laut Eucheuma sp. sekitar 193.700 ha (Anonim, 2007).

Status budidaya rumput laut di Sulawesi Selatan telah dinobatkan oleh pemerintah setempat sebagai salah satu komoditas unggulan di sektor perikanan. Terpilihnya komoditas rumput laut sebagai komoditas unggulan dilatarbelakangi oleh beberapa aspek yaitu budidaya rumput laut bersifat mudah dilakukan, bersifat massal, cepat panen, tidak padat modal, menyerap tenaga kerja, permintaan tinggi, dan harga yang menguntungkan (Nurdjana, 2006). Diharapkan mulai tahun 2012 Sulawesi Selatan sudah dapat menjadi sentra produksi rumput laut terbesar di Indonesia, sekaligus menempatkan Indonesia sebagai penghasil rumput laut terbesar kedua di dunia setelah Chili (Basmal \& Irianto, 2006). Untuk mempercepat laju perkembangan budidaya rumput laut, Pemerintah Sulawesi Selatan mentargetkan pada tahun 2009 status agrobisnis rumput laut meningkat menjadi agroindustri rumput laut (Anonim, 2007; Huseini, 2006).

Pemasaran hasil produk rumput laut dan harganya cukup stabil, baik untuk pasar ekspor maupun untuk pasar lokal, hal ini terlihat bahwa pada tahun 2006 produksi Gracilaria sp. dari hasil budidaya di tambak mencapai $15.144,8$ ton dengan Rp 213.946,6,- dan produksi Eucheuma sp. sebesar 403.201 ton dengan nilai sebesar Rp 604.801.500.000,- (Anonim, 2007). 


\section{POTENSI DAN KONDISI DAERAH SULAWESI SELATAN}

Potensi produksi perikanan di Sulawesi Selatan cukup besar yaitu produksi rumput laut sekitar $418.345,8$ ton/ tahun, ikan bandeng sebesar 58.508,9 ton/tahun, udang termasuk udang vanamei sebesar $27.617,7$ ton/tahun, kepiting termasuk rajungan sebesar $2.135,5$ ton/tahun, teripang sebesar 962,4 ton/tahun, dan ikan demersal (kerapu, kakap) sebesar $10.881,8$ ton/tahun. Selain potensi perikanannya yang cukup besar seperti telah disebutkan di atas potensi sumberdaya manusianya yang bergerak di bidang budidaya laut dan tambak juga cukup besar yaitu mencapai sekitar 50.755 RTP (Rumah Tangga Perikanan).

Mengingat potensi lahan budidaya perikanan dan jumlah sumberdaya manusia yang cukup mendukung maka peluang dan prospek pengembangan budidaya perikanan termasuk rumput laut di Sulawesi Selatan cukup besar. Khususnya di bidang budidaya tambak sebenarnya sudah berkembang sejak dua dasawarsa yang lalu, baik untuk budidaya udang windu maupun ikan bandeng. Namun, beberapa tahun terakhir ini budidaya udang windu anjlok akibat adanya serangan penyakit, sehingga menyebabkan banyak tambak-tambak bekas udang intensif yang tidak berproduksi (Anonim, 2007).

Untuk membangkitkan kembali usaha perudangan di Sulawesi Selatan pemerintah menganjurkan untuk memelihara udang vanamei sebagai pengganti budidaya udang windu di tambak, namun hal ini belum bisa berhasil dengan baik oleh karena masih terbatas bagi pengusaha yang bermodal kuat, sedangkan bagi masyarakat luas yang bermodal kecil atau lemah masih sulit untuk mengadopsinya oleh karena udang vanamei hanya cocok bila dibudidayakan secara semi intensif dan intensif yang memerlukan biaya besar (Tangko \& Pantjara, 2007). Budidaya udang vanamei juga belum bisa menjamin keberhasilan karena masih rentan terhadap serangan penyakit sehingga peluang mengalami kegagalan cukup besar. Sedangkan biaya operasional cukup besar dan harganya jauh lebih murah bila dibandingkan dengan harga udang windu. Dan seandainya selamat dari serangan penyakit atau berhasil panen, maka keuntungan yang diperoleh persatuan unit usaha sangat kecil. Sebagai contoh dalam budidaya udang vanamei secara tradisional dengan padat tebar 100 ribu ekor/ha memerlukan biaya investasi dan operasional sebanyak 30 juta rupiah, kemudian setelah pemeliharaan sekitar 3 bulan udang tersebut dipanen dengan sintasan 60\% (60.000 ekor) dengan bobot $20 \mathrm{~g} /$ ekor sehingga bobot total udang adalah $60.000 \times 20=1.200 .000 \mathrm{~g}(1.200 \mathrm{~kg})$ dengan harga Rp $27.500 / \mathrm{kg}$, sehingga harga penjualan udang yang diperoleh adalah $1.200 \times 27.500=$ Rp 33.000.000,-. Dari hasil usaha budidaya udang vanamei tersebut keuntungan bersih yang diperoleh adalah $\mathrm{Rp} 33.000 .000,---\mathrm{Rp}$ $30.000 .000,-=$ Rp 3.000.000,-/ha/mt. Keuntungan yang diperoleh tersebut adalah sangat kecil bila dibandingkan dengan usaha budidaya udang windu dengan pola budidaya yang sama. Sedangkan jenis penyakit yang sering menyerang budidaya udang vanamei adalah White Spot Syndrome (WSSV) dan Taura Syndrome Virus (TSV) merupakan jenis penyakit udang yang berbahaya karena dapat menyebabkan kematian total bagi udang putih termasuk udang vanamei yang dibudidayakan di tambak. Hal ini menyebabkan budidaya udang vanamei sulit berkembang di Sulawesi Selatan, sehingga untuk meningkatkan produktivitas tambak yang banyak terbengkalai, maka pemerintah setempat menganjurkan untuk budidaya rumput laut Gracilaria sp. baik secara monokultur maupun secara polikultur dengan ikan ataupun dengan udang windu. Ternyata beberapa tahun terakhir sudah banyak mantan pembudidaya udang beralih profesi menjadi pembudidaya Gracilaria sp. di tambak baik secara monokultur maupun dengan polikultur ikan bandeng dan udang windu. Produksi yang dapat dicapai pada pola budidaya polikultur tersebut adalah sekitar 7-12 ton/ha/siklus rumput laut basah (setara $700--1.200 \mathrm{~kg}$ rumput laut kering), 400--600 kg ikan bandeng/ha/siklus dan 300--400 kg udang windu/ha/siklus (Ratnawati \& Pantjara, 2002). Sedangkan di bidang budidaya laut baru budidaya Eucheuma sp. yang berkembang pesat dan untuk budidaya komoditas perikanan lainnya masih bersifat rintisan.

Berkembangnya budidaya rumput laut di Sulawesi Selatan baik di tambak maupun di laut disebabkan karena di samping sumberdaya lahannya yang masih cukup luas juga teknologinya sederhana dan tidak padat modal sehingga terjangkau oleh masyarakat luas yang berpengetahuan rendah dan bermodal kecil (Nurdjana, 2006; Anonim, 2007).

\section{PROSPEK PENGEMBANGAN BUDIDAYA RUMPUT LAUT}

Pengembangan budidaya rumput laut di Sulawesi Selatan mempunyai prospek yang sangat besar, karena rumput laut baik jenis Gracilaria sp. maupun Eucheuma sp. merupakan komoditas yang mempunyai nilai ekonomi tinggi dan tingkat pemanfaatannya sangat luas, mulai dari bahan makanan (minuman alginat, manisan kering, dodol, permen, jelly, agar kertas, agar tepung, dan minuman rumput laut), bahan obat-obatan, bahan pakan organisme di laut, pupuk tanaman dan penyubur tanah, serta sebagai pengemas transportasi yang sangat baik. Produk turunannya digunakan untuk industri tekstil, kertas, cat, komestika, bahan laboratorium, pasta gigi, 
es krim, dan lain-lain. Mengingat luasnya spektrum penggunaan rumput laut ini, maka upaya untuk meningkatkan produksinya melalui usaha budidaya prospeknya sangat besar untuk dikembangkan di Sulawesi Selatan.

\section{Rumput Laut Gracilaria sp.}

\section{Prospek Lahan Budidaya}

Luas tambak budidaya rumput laut Gracilaria sp. dan produksinya di Sulawesi Selatan tahun 2006 (Tabel 1).

Tabel 1. Luas tambak budidaya Gracilaria sp. (ha) dan produksinya (ton) per kabupaten di Sulawesi Selatan pada tahun 2006

\begin{tabular}{lrrr}
\hline $\begin{array}{l}\text { Kabupaten/ } \\
\text { kotamadya }\end{array}$ & $\begin{array}{c}\text { Luas tambak } \\
\text { (ha) }\end{array}$ & $\begin{array}{c}\text { Produksi } \\
\text { Gracilaria sp. } \\
\text { (ton) }\end{array}$ & \multicolumn{1}{c}{$\begin{array}{c}\text { Nilai (Rp) } \\
\text { (000,-) }\end{array}$} \\
\hline Bantaeng & 191 & - & - \\
Barru & 2,399 & 120 & 180,000 \\
Bone & 10,810 & $13.179,80$ & 19.769 .700 \\
Bulukumba & 4,000 & 6,005 & 9.007 .500 \\
Gowa & 137 & - & - \\
Jeneponto & 2,948 & - & - \\
Luwu & 6,374 & 83,538 & 125.307 .000 \\
Luwu Timur & 7,441 & - & - \\
Luwu Utara & 6,367 & $24.469,20$ & 36.703 .800 \\
Makassar & 1,180 & - & - \\
Maros & 9,388 & - & - \\
Palopo & 979 & $65.633,80$ & 98.450 .700 \\
Pangkep & 12,527 & $1.947,80$ & 2.921 .700 \\
Pare-Pare & 71 & - & - \\
Pinrang & 15,855 & 650 & 975,000 \\
Selayar & 858 & $3.019,50$ & 4.529 .228 \\
Sinjai & 678 & $5.890,50$ & 8.835 .750 \\
Takalar & 4,100 & $1.300,00$ & 1.950 .000 \\
Wajo & 11,876 & 8,193 & 12.289 .500 \\
\hline \multicolumn{1}{c}{ Total } & $\mathbf{5 0 , 2 0 1}$ & $\mathbf{1 5 . 1 4 4 , 8 0}$ & $\mathbf{2 1 3 . 9 4 9 , 6 0}$ \\
\hline Sul & & &
\end{tabular}

Sumber: Anonim (2007)

Dari Tabel 1 terlihat bahwa kabupaten yang terluas lahan pertambakannya adalah Kabupaten Pinrang dan tersempit adalah Pare-Pare, sedangkan yang tertinggi produksi dan nilai rumput lautnya adalah Kabupaten Luwu Utara dan terendah adalah Kabupaten Barru. Sedangkan kabupaten yang mempunyai wilayah pantai tapi tidak ada produksinya adalah Kotamadya Makassar, Pare-Pare, Kabupaten Luwu Utara, Bantaeng, Jeneponto, Gowa, dan Maros. Semua daerah yang belum berproduksi tersebut kemungkinan lahan pertambakannya tidak cocok untuk budidaya rumput laut Gracilaria sp. seperti telah disebutkan di muka, atau memang belum sempat melakukannya oleh karena masih mengandalkan budidaya udang windu atau udang vanamei dan bandeng (Tangko \& Pantjara, 2007).

Budidaya rumput laut Gracilaria sp. di tambak realisasinya masih sangat rendah yaitu $15.144,8$ ton/tahun bila dibandingkan dengan potensi lahan yang ada (50.201 ha), sehingga prospek pengembangannya ke depan masih cukup besar. Sebagai estimasi kasar seandainya luas lahan tambak yang ada (50.201 ha) semuanya terealisasi, maka produksi rumput laut Gracilaria sp. per hektar per siklus adalah 50.201 ha x (7-12 ton) $=(351.407-602.412$ ton/ha/ siklus), oleh karena panen dapat dilakukan sebanyak 6 kali per tahun, maka produksi total rumput laut Gracilaria sp. per tahun yang dapat dicapai adalah $6 \times$ (351.407602.412 ton/tahun). Sayangnya data tentang luasnya tambak yang telah digunakan untuk budidaya Gracilaria sp. di tambak sampai sekarang belum tersedia, namun sebagian besar daerah kabupaten di Sulawesi Selatan telah melakukan budidaya Gracilaria sp. di tambak (Tabel 1).

Belum meluasnya budidaya Gracilaria sp. di tambak, diduga karena masih adanya permasalahan atau kendala yang sering ditemukan di lapangan terutama yang berkaitan dengan jenis tambak di masing-masing daerah. Keberhasilan budidaya Gracilaria sp. di tambak sangat tergantung dari jenis tanah dasar dan sumber airnya. Menurut hasil penelitian, bahwa lahan tambak yang cocok untuk budidaya Gracilaria sp. adalah lahan pertambakan yang jenis tanahnya lempung berpasir dan lokasinya berbatasan dengan pantai sebagai sumber air (Gambar 1). Selain jenis tanah dasar tambak, jumlah, dan kualitas produksi Gracilaria sp. di tambak sangat ditentukan oleh kualitas bibit dan mutu air yang sesuai untuk pertumbuhan

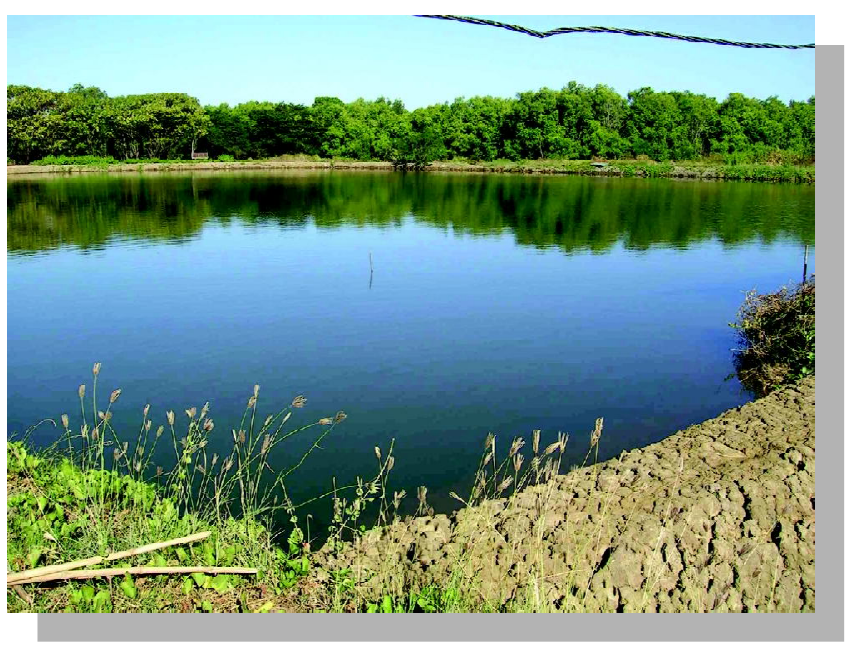

Gambar 1. Tambak budidaya Gracilaria sp. di Kabupaten Luwu 
rumput laut Gracilaria sp. dan frekuensi penggantian air. Menurut Nurdjana (2006), salah satu titik kritis dalam budidaya Gracilaria sp. di tambak adalah masalah penggantian air. Budidaya Gracilaria sp. dengan penggantian air setiap minggu dapat mencapai produksi sekitar 10-12 ton Gracilaria sp. basah/ha/siklus (Susanto, 2006).

\section{Prospek Teknologi dan Produksi}

Pada umumnya pembudidaya rumput laut Gracilaria sp. di Sulawesi Selatan menggunakan metode polikultur rumput laut dengan ikan bandeng dan udang windu di mana rumput laut sebagai komoditas utama, ikan bandeng, dan udang windu sebagai usaha sampingan. Padat tebar yang diaplikasikan adalah tergantung dari luas tambak yang digunakan, namun yang umum adalah $1.000--1.500 \mathrm{~kg} / \mathrm{ha} /$ siklus Gracilaria sp. dipolikulturkan dengan 1.500--2.000 ekor/ha/mt ikan bandeng dan 5.000--10.000 ekor/ha/siklus udang windu, dengan masa pemeliharaan 45 hari untuk Gracilaria sp. dan 4--6 bulan untuk ikan bandeng, serta 3--4 bulan untuk udang windu per siklus atau per musim tanam. Dalam satu tahun dapat dilakukan panen Gracilaria sp. 6 kali, sedangkan ikan bandeng dan udang windu hanya 1--2 kali (Ratnawati \& Pantjara, 2002).

Dari segi analisis biologis tujuan utama polikultur rumput laut dengan bandeng adalah bandeng dapat memakan lumut yang menempel pada rumput laut sehingga lumut tersebut tidak mengganggu pertumbuhan rumput laut. Namun bandeng yang berukuran besar justru dapat memakan rumput laut, untuk mencegah hal tersebut bandeng pada ukuran 100 g/ekor keatas dipindahkan ke petak tambak pembesaran sebelum mencapai ukuran konsumsi atau dipanen. Sedangkan udang windu mulai ukuran benur sampai ukuran besar tidak memakan rumput laut, sehingga udang windu tersebut dapat dipolikulturkan dengan rumput laut sampai ukuran konsumsi. Oleh karena masa pemeliharaan bandeng dan udang windu lebih lama dibandingkan dengan rumput laut, maka dalam satu siklus pemeliharaan bandeng dan udang windu dapat dilakukan panen rumput laut 3--4 kali baru dilakukan panen bandeng dan udang windu (Tangko \& Pantjara, 2007).

Dari segi optimalisasi penggunaan lahan maka polikultur rumput laut dengan bandeng dan udang windu adalah bertujuan untuk meningkatkan produktivitas tambak dan sekaligus untuk peningkatan pendapatan bagi para pembudidaya tambak, oleh karena selain dapat panen rumput laut sebagai komoditas utama juga dapat panen bandeng dan udang sebagai komoditas tambahan. Baik secara teknis maupun secara ekonomi polikultur ketiga komoditas (rumput laut, bandeng, dan udang windu) sangat menguntungkan karena kehadiran bandeng dengan ukuran di bawah 100 g/ekor dan udang tidak mengganggu pertumbuhan rumput laut. Oleh karena polikultur rumput laut dengan bandeng dan udang windu tidak terjadi persaingan ruang di mana rumput laut hidup di dasar, sedangkan bandeng lebih banyak hidup pada lapisan badan air, begitu pula udang windu dapat mengisi relung ekologi di sela-sela dan di bawah tumpukan rumput laut. (Tangko $\&$ Pantjara, 2007). Dari sisi lain polikultur rumput laut dengan bandeng dan udang windu dapat terjadi penghematan lahan dan biaya operasional oleh karena kehadiran ikan bandeng dan udang windu tidak mengganggu pertumbuhan rumput laut (Ratnawati \& Pantjara, 2002).

Produksi Gracilaria sp. basah yang dicapai dengan metode budidaya tersebut adalah sekitar 7--12 ton/ha/ siklus (Gambar 2) atau setara dengan 700--1.200 kg Gracilaria sp. kering, sedang produksi ikan bandeng dan windu sekitar $400--600$ kg/ha/siklus dan $300--300$ kg/ha/ siklusjika selamat dari penyakit. Sedangkan produksi total rumput laut Gracilaria sp. yang dicapai di Sulawesi Selatan pada tahun 2006 dapat dilihat pada Tabel 1.

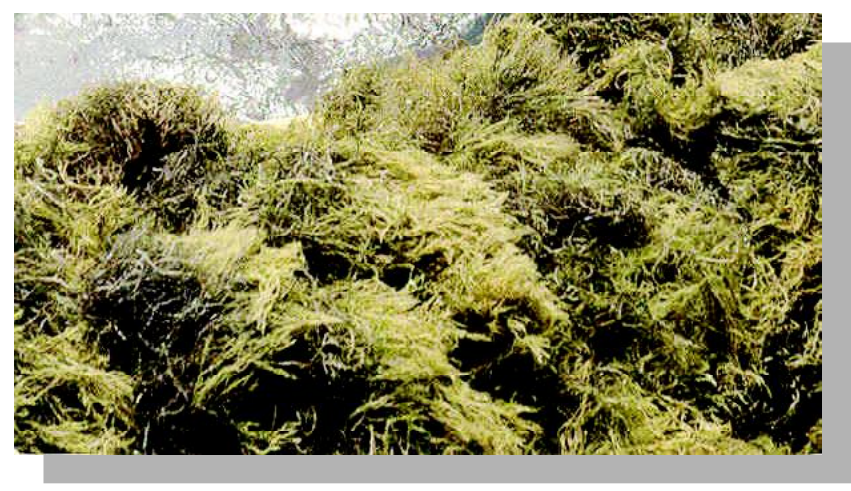

Gambar 2. Gracilaria sp. basah hasil panen di Kabupaten Luwu

\section{Rumput Laut Eucheuma sp.}

\section{Prospek Lahan Budidaya}

Berdasarkan potensi lahan yang ada maka prospek peningkatan produksi rumput laut Eucheuma sp. di Sulawesi Selatan cukup besar. Data potensi lahan pada tahun 2006 disajikan pada Tabel 2.

Dari Tabel 2 terlihat bahwa potensi budidaya laut termasuk budidaya rumput laut (Eucheuma sp.) terbesar di Kabupaten Selayar dan Kabupaten Bone dan terkecil di Kabupaten Gowa dan Luwu Utara. Realisasi budidaya termasuk rumput laut terbesar terjadi di Kabupaten Selayar, Palopo, Jeneponto, dan Bulukumba, realisasi budidaya terkecil terjadi di Kabupaten Luwu Timur, Wajo, 
Tabel 2. Data lahan budidaya rumput laut Eucheuma sp. di Sulawesi Selatan pada tahun 2006

\begin{tabular}{lrrr}
\hline $\begin{array}{c}\text { Kabupaten/ } \\
\text { kotamadya }\end{array}$ & $\begin{array}{r}\text { Panjang pantai } \\
\left(\mathbf{k m}^{\mathbf{2}}\right)\end{array}$ & $\begin{array}{c}\text { Potensi } \\
(\mathbf{h a})\end{array}$ & $\begin{array}{c}\text { Realisasi } \\
\mathbf{( m}^{\mathbf{2}} \mathbf{)}\end{array}$ \\
\hline Bantaeng & 35 & 3,500 & 1,640 \\
Barru & 78 & 7,800 & 845 \\
Bone & 130,45 & 13,046 & 87 \\
Bulukumba & 124 & 12,400 & 9,840 \\
Gowa & 2 & 200 & - \\
Jeneponto & 85 & 9,500 & 15,344 \\
Luwu & 123 & 12,300 & - \\
Luwu Timur & 106 & 10,600 & 26 \\
Luwu Utara & 52,6 & 520 & - \\
Makassar & 35,7 & 3,750 & - \\
Maros & 36 & 3,600 & - \\
Palopo & 20 & 2,000 & 16,300 \\
Pangkep & 79 & 7,900 & 46 \\
Pare-Pare & 11,6 & 1,160 & - \\
Pinrang & 95 & 9,500 & 1,500 \\
Selayar & 670 & 67,000 & 16,400 \\
Sinjai & 31 & 3,100 & 500 \\
Takalar & 108 & 10,800 & 214 \\
Wajo & 103 & 10,300 & 35 \\
\hline \multicolumn{1}{c}{ Total } & $\mathbf{1 , 9 3 7}$ & $\mathbf{1 9 3 , 7 0 0}$ & $\mathbf{6 2 , 7 3 1}$ \\
\hline
\end{tabular}

Sumber: Anonim (2007)

Pangkep, dan Bone. Sedangkan kabupaten yang belum ada realisasi budidaya rumput laut adalah Luwu, Maros, Pare-Pare, Gowa, dan Luwu Utara.

Di Sulawesi Selatan potensi lahan budidaya rumput laut Eucheuma sp. sekitar 193.700 ha dan baru terealisasi sekitar $62.371 \mathrm{~m}^{2}$ atau 6,2 ha $(3,2 \%$ dari potensi yang ada dengan produksi total sekitar 403.201 ton/tahun sehingga prospek pengembangannya ke depan masih sangat besar. Sebagai estimasi kasar yaitu seandainya semua potensi lahan budidaya rumput laut Eucheuma sp. yang luasnya 193.700 ha terealisasi maka produksi rumput laut basah yang dapat dicapai per siklus adalah $193.700 \mathrm{x}$ $(8--10$ ton $)=(1.549 .600-1.937 .000$ ton/ha/siklus $)$. Panen rumput laut dapat dilakukan 6 kali setahun, maka produksi total yang dapat dicapai per tahun adalah $6 \times(1.549 .600-$ 1.937 .000 ton/ha/siklus $)=(9.297 .600-11.622 .000$ ton/ tahun). Belum terealisasinya potensi lahan budidaya secara optimal disebabkan oleh masih adanya permasalahan di lapangan di antaranya yaitu berupa kekurangan modal kerja bagi masyarakat pembudidaya. Masyarakat banyak yang melakukan budidaya rumput laut karena budidaya rumput laut Eucheuma sp., bersifat low teknologi dan massal, cepat panen, tidak padat modal, menyerap tenaga kerja, dan harga yang tinggi (Nurdjana, 2006). Di Sulawesi Selatan ada beberapa desa pantai yang terkenal sebagai sentra budidaya rumput laut Eucheuma sp., yaitu Desa Laikang di Kabupaten Takalar, Desa Samataring di Kabupaten Sinjai, Desa Bontojai di Kabupaten Jeneponto, Desa Palantikang di Kabupaten Bantaeng, Desa Tana Lemo di Kabupaten Bulukumba, Desa Suppa di Kabupaten Pinrang, Desa Panyula di Kabupaten Bone, dan sebagainya. Masyarakat di desa tersebut tingkat kesejahteraannya lebih maju bila dibandingkan dengan desa pantai lainnya yang belum melakukan budidaya rumput laut. Hal ini sesuai dengan pendapat Nurdjana (2006) bahwa budidaya rumput laut dapat menyerap tenaga kerja dan pengentas kemiskinan.

\section{Prospek Teknologi dan Produksi}

Teknologi budidaya rumput laut Eucheuma sp. cukup sederhana dan mudah diaplikasikan bagi masyarakat pembudidaya, oleh karena itu usaha budidaya Eucheuma sp. cepat berkembang. Di Sulawesi Selatan metode budidaya yang banyak diaplikasikan oleh masyarakat pembudidaya adalah longline atau metode rawai (apung), metode ini sangat praktis dan murah biayanya karena bahan utama yang digunakan yaitu berupa beberapa batang bambu, tali nilon atau tali rafia, botol plastik bekas, dan semen beton sebagai jangkar.

Fungsi dari masing-masing bahan tersebut adalah sebagai berikut: (1) bambu berfungsi sebagai tempat untuk mengikatkan tali bentangan; (2) tali nilon No. 4 dibentangkan dengan jarak $50 \mathrm{~m}$ dan masing-masing ujungnya diikatkan pada bambu; (3) botol plastik bekas berfungsi sebagai pelampung setiap tali bentangan; (4) bola plastik sebagai pelampung utama pada kedua ujung tali bentangan; (5) semen beton berfungsi sebagai jangkar agar posisi bentangan tali tetap stabil dan tidak hanyut terbawa arus atau ombak; (6) tali nilon No. 1 dengan fungsi sebagai pengikat rumpunan bibit rumput laut dengan jarak tanam $25 \mathrm{~cm}$. Sedangkan lama pemeliharaan tergantung dari jenis rumput laut yang dipelihara namun yang umum adalah 45 hari/siklus, sehingga dalam satu tahun dapat dilakukan panen sebanyak 6--7 kali (Yunus, 2006). Lokasi budidaya rumput laut dan letak posisi rakit apung budidaya rumput di laut dapat dilihat pada Gambar 3 dan 4.

Produksi yang dicapai pada setiap unit rakit apung tergantung dari jumlah dan panjang bentangan tali yang digunakan. Untuk satu unit rakit apung yang terdiri atas 25 tali bentangan dengan panjang masing-masing 50 meter dengan padat tebar bibit Eucheuma sp. sekitar 1 ton, dengan produksi rumput laut basah sekitar 8--10 ton/mt, atau setara dengan $800--1.000 \mathrm{~kg}$ rumput laut kering (Gambar 5 ). 


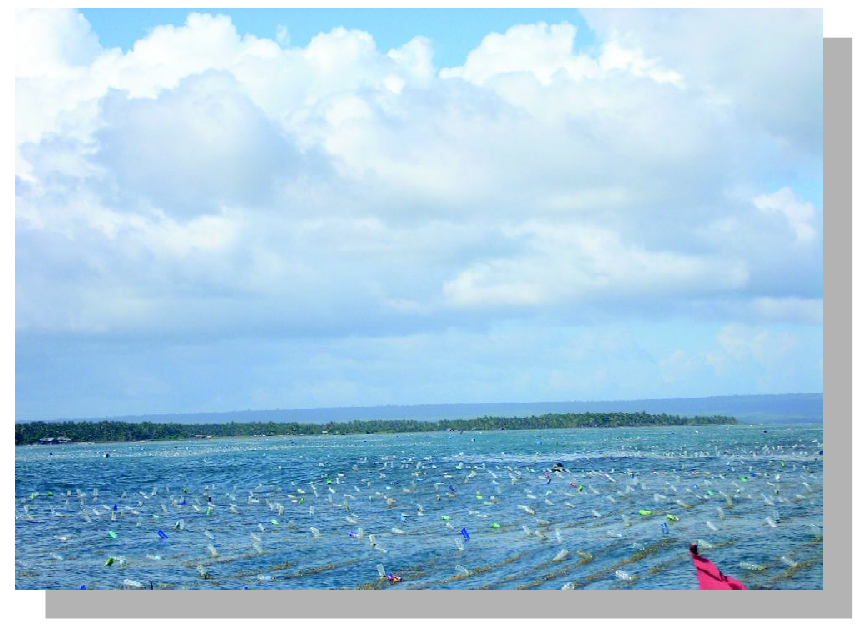

Gambar 3. Lokasi budidaya Eucheuma sp. di Kabupaten Bulukumba

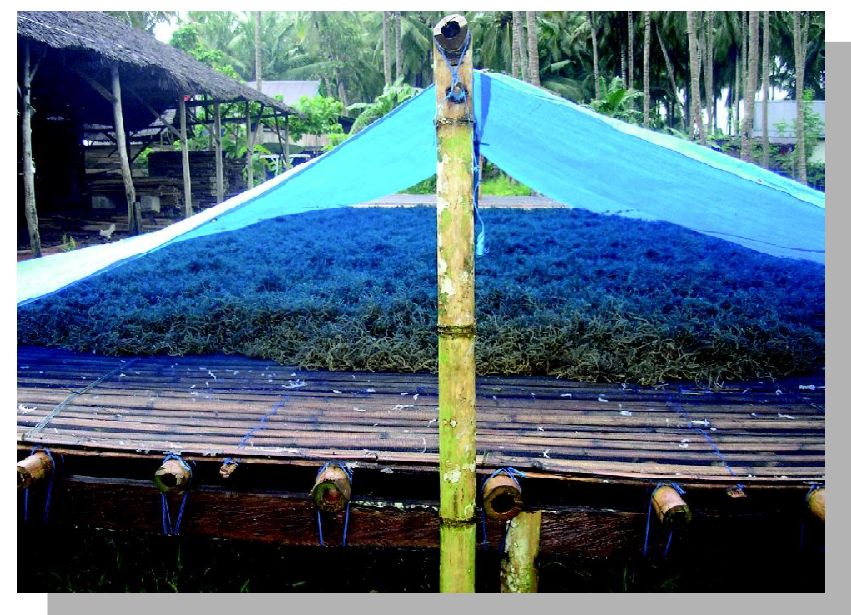

Gambar 5. Eucheuma sp. basah hasil panen di Kabupaten Bulukumba

Total produksi rumput laut Eucheuma sp. di Sulawesi Selatan dari hasil budidaya di laut pada tahun 2006 adalah sebesar 403.201 ton dengan nilai sebesar Rp 604.801.500.000,- jumlah produksi pada setiap kabupaten (Tabel 3), sedangkan total ekspor rumput laut dan nilainya selama 5 tahun terakhir (2002--2006) disajikan pada Gambar 6.

Pada Tabel 3 terlihat bahwa produksi dan nilai rumput laut Eucheuma sp. tertinggi di Kabupaten Jeneponto dan Takalar, dan terendah di Kabupaten Barru dan Luwu Timur. Sedangkan kabupaten yang belum berproduksi sampai sekarang adalah Luwu, Makassar, Maros, Pare-Pare, Gowa, dan Luwu Utara.

Pada Gambar 6 terlihat bahwa volume ekspor dan nilai rumput laut Gracilaria sp. dan Eucheuma sp. tertinggi pada tahun 2006 dan terendah pada tahun 2002 atau terjadi

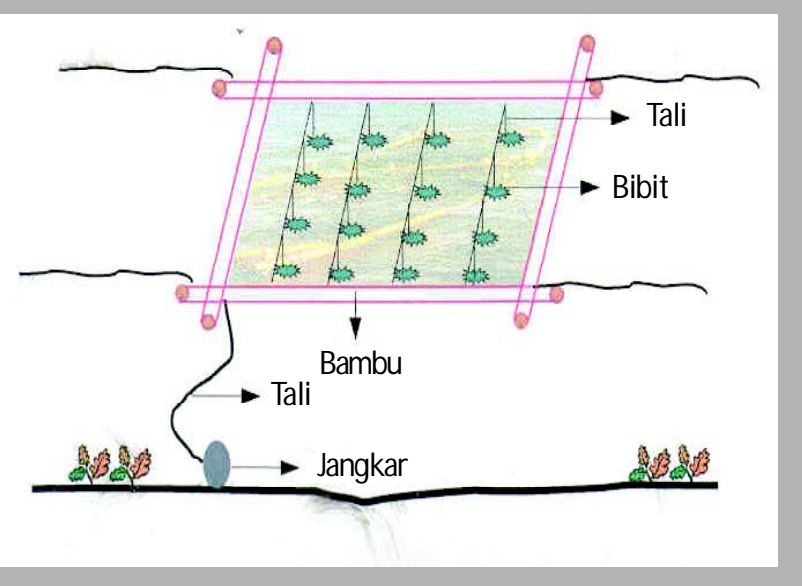

Gambar 4. Model rakit apung budidaya Eucheuma sp. yang umum diaplikasikan di Sulawesi Selatan

Tabel 3. Produksi rumput laut Eucheuma sp. di Sulawesi Selatan tahun 2006

\begin{tabular}{lrr}
\hline Kabupaten & $\begin{array}{c}\text { Eucheuma sp. } \\
\text { (ton) }\end{array}$ & \multicolumn{1}{c}{$\begin{array}{c}\text { Nilai } \\
\text { (Rp) }\end{array}$} \\
\hline Bantaeng & $23.072,00$ & 34.609 .000 .000 \\
Barru & 280 & 420.000 .000 \\
Bone & $16.950,90$ & 28.426 .350 .000 \\
Bulukumba & $20.877,60$ & 31.316 .700 .000 \\
Jeneponto & $136.181,60$ & 204.272 .400 .000 \\
Luwu Timur & $1.562,00$ & 2.324 .000 .000 \\
Palopo & $5.375,50$ & 8.063 .000 .000 \\
Pangkep & $19.920,00$ & 29.880 .000 .000 \\
Pinrang & $6.446,00$ & 9.669 .000 .000 \\
Selayar & $40.124,00$ & 60.186 .000 .000 \\
Sinjai & $15.034,00$ & 22.551 .000 .000 \\
Takalar & $111.945,00$ & 167.917 .500 .000 \\
W ajo & $5.413,30$ & 8.146 .990 .000 \\
\hline \multicolumn{1}{c}{ Jumlah } & $\mathbf{4 0 3 , 2 0 1}$ & $\mathbf{6 0 4 . 8 0 1 . 5 0 0 . 0 0 0}$ \\
\hline
\end{tabular}

Sumber: Anonim (2007)

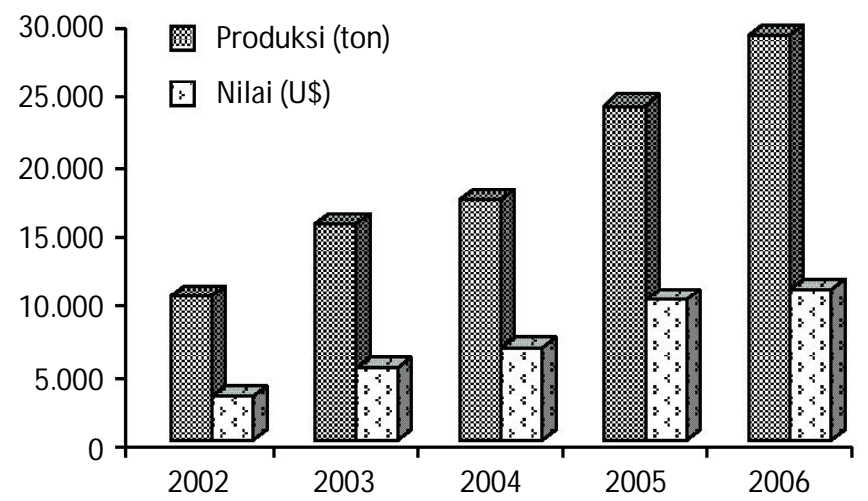

Gambar 6. Ekspor dan nilai rumput laut di Sulawesi Selatan tahun 2002--2006 
peningkatan setiap tahunnya. Hal ini disebabkan karena jumlah pembudidaya dan luas lahan budidaya untuk rumput laut semakin luas pula. Ekspor rumput laut diperkirakan akan semakin meningkat untuk tahun mendatang.

\section{KENDALA DAN PERMASALAHAN}

Dalam budidaya Gracilaria sp. di tambak kendala yang dihadapi adalah masih banyaknya lahan tambak yang tidak cocok untuk budidaya Gracilaria sp. seperti tingkat kemasaman tinggi, jenis tekstur tanahnya dominan pasir atau liat, salinitas yang sangat tinggi pada musim kemarau dan sebaliknya sangat rendah pada musim hujan. Kondisi tambak seperti ini tidak optimal untuk pertumbuhan rumput laut bahkan dapat menyebabkan kematian massal bagi rumput laut yang dibudidayakan (Sugiarto et al.,1978; Akrim, 2006).

Sedangkan untuk budidaya Eucheuma sp. di laut kendala yang sering timbul adalah gangguan ombak atau gelombang besar terutama pada musim hujan. Gempuran ombak atau gelombang ini selain dapat menyebabkan thallus rumput laut rusak atau patah-patah, juga dapat menyebabkan pengadukan lumpur yang dapat menyebabkan kekeruhan air di lokasi budidaya. Kondisi air yang keruh dapat mengganggu pertumbuhan rumput laut karena adanya sedimentasi yang menempel pada rumput laut. Selain faktor cuaca, faktor lain yang sering mengganggu atau merusak rumput laut yang dipelihara adalah adanya serangan ikan predator seperti ikan beronang dan serangan penyakit iceice.

Permasalahan lain yang sering dialami pembudidaya rumput laut baik di tambak maupun di laut adalah sulitnya memperoleh bibit yang bermutu atau berkualitas. Hal ini disebabkan di Sulawesi Selatan belum ada kebun bibit yang dapat berproduksi secara berkesinambungan yang sangat diperlukan dalam rangka peningkatan produksi rumput laut. Padahal mutu bibit sangat menentukan pertumbuhan dan produksi yang dapat dicapai oleh karena bibit yang bermutu pertumbuhannya cepat dan produksinya tinggi yaitu 1 ons bibit unggul dapat mencapai bobot 1--1,5 kg selama 45 hari bila dipelihara dalam lingkungan budidaya yang optimal. Sedangkan sebaliknya bibit yang ada adalah bibit yang tidak bermutu atau sudah merupakan galur keturunan rumput yang sudah panjang, pertumbuhannya lambat, dan tidak mengambang sehingga produksinya rendah (Hikmayani \& Purnomo, 2006).

\section{KESIMPULAN DAN SARAN}

1. Produksi total rumput laut yang telah dicapai pada tahun 2006 yaitu Gracilaria sp. sebesar 403.201 ton dan rumput laut Eucheuma sp. sebesar 15.144,8 ton. Berdasarkan potensi lahan budidaya yang ada yaitu
50.201 ha tambak untuk budidaya Gracilaria sp. dan 193.700 ha untuk budidaya Eucheuma sp. maka prospek peningkatan produksi yang dapat dicapai ke depan yaitu untuk rumput laut Gracilaria sp. adalah 50.201 x $(7--12$ ton $)=(351.407--602.412$ ton/ha/siklus $)$, dengan produksi total per tahun adalah 6 × (351.407--602.412) $=$ (2108.442--3614.472 ton/tahun). Dan prospek produksi Eucheuma sp. adalah 193.700 ha x (8--10 ton) $=(1.549 .600-1.937 .000$ ton/ha/siklus) dengan produksi total per tahun adalah $6 \times$ (1.549.600-$1.937 .000)=(9.297 .600--11.622 .000$ ton/tahun). Prospek peningkatan produksi rumput laut tersebut di atas didukung oleh tersedianya teknologi budidaya yang memadai dan sumberdaya tenaga manusia sekitar 50.755 RTP (Rumah Tangga Perikanan).

2. Permasalahan yang dihadapi dalam pengembangan budidaya rumput laut di Sulawesi Selatan adalah belum berkesinambungannya kebun bibit rumput laut yang berkualitas baik jenis Gracilaria sp. maupun jenis Eucheuma sp. Untuk budidaya Eucheuma sp. di laut yaitu adanya serangan penyakit ice-ice dan ikan predator, pada musim hujan (musim barat) ombak sangat besar menyebabkan kekeruhan air akibat adanya pengadukan lumpur serta thallus rumput laut banyak yang patah-patah. Sedangkan untuk budidaya Gracilaria sp. di tambak permasalahan yang sering muncul yaitu masih banyaknya tambak yang tidak cocok pertumbuhan rumput laut Gracilaria sp., hal ini berkaitan dengan tekstur tanah dasar tambak dan tingkat kemasaman tanah yang tinggi serta tingkat salinitas air tambak yang tinggi pada musim kemarau dan sebaliknya salinitas sangat rendah pada musim hujan.

3. Untuk mempercepat pengembangan dan peningkatan produksi rumput laut di Sulawesi Selatan disarankan pemerintah menyediakan kebun bibit yang berkesinambungan dan memberikan pinjaman modal kerja bagi masyarakat pembudidaya. Sedangkan untuk meningkatkan volume dan kualitas produk serta harga yang terjamin sebaiknya dilakukan model usaha budidaya rumput laut dalam bentuk klaster.

\section{DAFTAR PUSTAKA}

Anonim. 2007. Rumput laut VS kemiskinan. Trobos, Media Agribisnis Peternakan dan Perikanan. Jakarta. 93(VIII): 90.

Akrim, D. 2006. Perkembangan Industri Rumput Laut di Indonesia. Diseminasi Teknologi dan Temu Bisnis Rumput Laut. Badan Riset Perikanan dan Kelautan. Makassar, 11 September 2006. p. 50-70. 
Basmal, J. dan H.E. Irianto. 2006. Teknologi Pascapanen Rumput Laut. Diseminasi Teknologi dan Temu Bisnis Rumput Laut. Badan Riset Kelautan dan Perikanan. Makassar, 11 September 2006. p. 71- 105.

Hikmayani, Y. dan A.H. Purnomo. 2006. Analisis Pemasaran dan Kelembagaan Rumput Laut di Indonesia. Makalah Temu Bisnis Rumput Laut. Badan Riset Kelautan dan Perikanan. Makassar, 11 September 2006. $21 \mathrm{pp}$.

Huseini, M. 2006. Rumput Laut: Pemanfaatan dan Pemasarannya. Diseminasi Teknologi dan Temu Bisnis Rumput Laut. Badan Riset Kelautan dan Perikanan. Makassar, 11 September 2006. p. 71- 105.

Mubarak, H., Sulistijo, A. Djamali, dan O.K. Sumadhiharga. 1998. Sumberdaya Rumput Laut. Potensi dan penyebaran Sumberdaya Ikan laut di Perairan Indonesia. Komisi Nasional Pengkajian Stok Sumberdaya Ikan Laut. LIPI. p. 226- 241.

Nontji, A. 2005. Laut Nusantara. Penerbit Djambatan. Jakarta. 367 pp.

Nurdjana, M. 2006. Pengembangan Budidaya Rumput Laut di Indonesia. Diseminasi Teknologi dan Temu Bisnis Rumput Laut. Badan Riset Kelautan dan Perikanan. Makassar, 11 September 2006. p. 1-35.
Ratnawati, E. dan B. Pantjara. 2002. Analisa Ekonomi Budidaya Rumput Laut di Tambak Tanah Sulfat Masam, Desa Lamasi Pantai Luwu Utara Sulawesi Selatan. Makalah disampaikan pada Seminar Nasional Rumput Laut, M ini Simposium M ikro algae, dan KongresI Ikatan Fisikologi Indonesia. Makassar 23- 25 Oktober 2002. $13 \mathrm{pp}$.

Sugiarto, A. Sulistijo, W.S. Atmadja, dan H. Mubarak. 1978. Rumput Laut (algae), manfaat, potensi dan usaha budidayanya. Lembaga Oceanologi Nasional - LIPI. Jakarta. 61 pp.

Susanto, A.B. 2006. Teknologi Terapan Rumput Laut, Diseminasi Teknologi dan Temu Binis Rumput Laut. Badan Riset Kelautan dan Perikanan. Makassar 11 Septemper 2006. 15 pp.

Tangko, A.M. dan B. Pantjara. 2007. Dinamika Pertambakan Perikanan Di Sulawesi Selatan kurun Waktu (1990-2005). M edia Akuakultur. 2(2): 118- 123.

Yunus, Y.M. 2006. Kiat Sukses Budidaya Rumput Laut. Diseminasi Teknologi dan Temu Bisnis Rumput Laut. Badan Riset Kelautan dan Perikanan. Makassar, 11 September 2006. p. 35- 49. 